\title{
Correction to: The Origin(s) of Modern Amphibians: A Commentary
}

\author{
David Marjanović ${ }^{1} \cdot$ Michel Laurin $^{1}$
}

Published online: 29 May 2020

(c) Springer Science+Business Media, LLC, part of Springer Nature 2020

\section{Correction to: Evol Biol}

https://doi.org/10.1007/s11692-009-9065-8

The page where the original version of this article is posted unfortunately contained an error. In that page, the supplementary material is not currently included along with the article and this problem has been corrected with this erratum.

Publisher's Note Springer Nature remains neutral with regard to jurisdictional claims in published maps and institutional affiliations.

Electronic supplementary material The online version of this article (https://doi.org/10.1007/s11692-020-09504-y) contains supplementary material, which is available to authorized users.

The original article can be found online at https://doi.org/10.1007/ s11692-009-9065-8.

Michel Laurin

michel.laurin@upmc.fr

1 Département Histoire de La Terre, UMR CNRS 7207

Centre de Recherches Sur La Paléobiodiversité Et Les

PaléoenvironnementsMuséum National D'Histoire

NaturelleBâtiment de Géologie, case postale 48, 57 rue

Cuvier, 75231 Paris cedex 05, France 